Sediment Characteristics of

Streams in the Eastern

Piedmont and Western Coastal Plain Regions of

North Carolina

GEOLOGICAL SURVEY WATER-SUPPLY PAPER 1798-O

Prepared in cooperation with the North Carolina Department of Natural and Economic Resources 


\section{Sediment Characteristics of}

Streams in the Eastern

\section{Piedmont and Western Coastal}

\section{Plain Regions of}

North Carolina

By CLYDE E. SIMMONS

SEDIMENTATION IN SMALL DRAINAGE BASINS

GEOLOGICAL SURVEY WATER-SUPPLY PAPER 1798-O

Prepared in cooperation with the

North Carolina Department of

Natural and Economic Resources

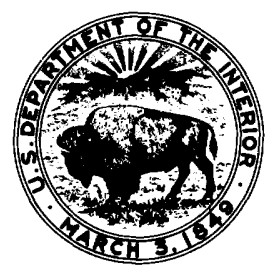




\section{UNITED STATES DEPARTMENT OF THE INTERIOR}

THOMAS S. KLEPPE, Secretary

\section{GEOLOGICAL SURVEY}

V. E. McKelvey, Director

Library of Congress Cataloging in Publication Data

Simmons, Clyde E.

Sediment characteristics of streams in the eastern Piedmont and western Coastal

Plain regions of North Carolina.

(Sedimentation in small drainage basins) (Geological Survey water-supply paper; 1798-0)

Bibliography: $p$.

Supt. of Docs.: I 19.13:1798-O

1. Sediments (Geology)-North Carolina. 2. Rivers-North Carolina. I. North Carolina. Dept. of Natural and Economic Resources. II. Title. IIII. Series. IV. Series: United States. Geological Survey. Water-supply paper; 1798-O. 


\section{CONTENTS}

\begin{tabular}{|c|c|}
\hline & Page \\
\hline & IV \\
\hline Inglish equivalents & VI \\
\hline & 01 \\
\hline 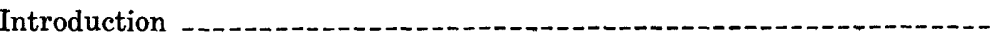 & 2 \\
\hline Purpose and scope & 2 \\
\hline Previous sediment studies & 2 \\
\hline atures of the study area & 2 \\
\hline Physiography & $\overline{2}$ \\
\hline Geology and soils & 4 \\
\hline Climate & 6 \\
\hline Vegetation - & 6 \\
\hline homotoniation & 7 \\
\hline Methods of sampling and analysis & 7 \\
\hline Unmeasured sediment discharge & 7 \\
\hline Method of computations & 10 \\
\hline Suspended-sediment concentrations and yields & 15 \\
\hline Effects of land use on suspended sediment & 15 \\
\hline Major river basins & 18 \\
\hline Roanoke River basin & 18 \\
\hline Pamlico River basin & 22 \\
\hline Neuse River basin & 22 \\
\hline Cape Fear River basin & 23 \\
\hline le size of suspended sediment & 25 \\
\hline 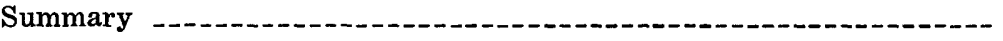 & 25 \\
\hline ted referen & 27 \\
\hline
\end{tabular}

\section{ILLUSTRATIONS}

FIGURE 1. Map showing study area and locations of sediment-sampling stations

2. Generalized geology of study area

03

3. Graphs showing comparison of annual precipitation during the study period with long-term averages at selected points

4. Duration curve of daily mean discharge of Eno River near Durham, 1969-73 water years

5. Sediment-transport curve for Eno River near Durham, 196973 water years 
FIGURE 6. Map showing average annual sediment yields, 1969-73 _..--

7. Map showing ranges in approximate suspended-sediment concentrations equaled or exceeded 1 percent and 95 percent of the time during 1969-73

8. Graph showing relation of percentage of forest cover and average annual suspended-sediment yield for sediment stations
9. Graph showing percentage distribution of clay, silt, and sand in suspended-sediment samples collected during floods at selected stations, 1969-73

\section{TABLES}

TABLE 1. Computations of average annual suspended-sediment yield of the Eno River near Durham, 1969-73

2. Comparison of sediment yields at Yadkin River near Yadkin College using the sediment-rating curve method and daily sediment samples

3. Summary of computed annual suspended-sediment yields and other sediment characteristics

4. Summary of land use of the subbasins

5. Locations of sampling stations used in this report

\section{GLOSSARY}

Because many of the terms related to fluvial sediment are not completely standardized, the following definitions are included as a guide to the terminology used in this report:

Bed material. The shifting part of the granular material that forms the bed of most streams.

Bedload or sediment discharged as bedload. Includes both the sediment that moves in continuous contact with the streambed and the material that bounces along the bed in short skips or leaps.

Drainage area of a stream at a specified location. That area, measured in a horizontal plane, enclosed by a topographic divide from which direct surface runoff from precipitation normally drains by gravity into the stream above the specified point. Figures of drainage area given herein include all closed basins, or noncontributing areas, within the area.

Particle size. The diameter, in millimetres $(\mathrm{mm})$, of suspended sediment or bed material determined by either sieve or other sedimentation methods. 
Particle-size classification. Agrees with recommendations made by the American Geophysical Union Subcommittee on Sediment Terminology. The classification is as follows:

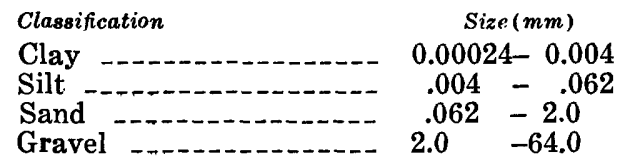

Sediment. Solid material that originates mostly from disintegrated rocks and is transported by, suspended in, or deposited from water; it includes chemical and biochemical precipitates and decomposed organic material such as humus.

Sediment-transport curve. Usually the relation between water discharge and suspended-sediment discharge, but it can be between water discharge and bedload discharge or between water discharge and total sediment discharge (sum of sediment discharge in suspension and bedload).

Suspended sediment. The sediment that at any given time is maintained in suspension by the upward components of turbulent currents or that exists in suspension as a colloid.

Suspended-sediment concentration The velocity-weighted concentration of sediment in the sampled zone (from the water surface to a point approxi-

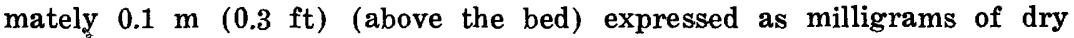
sediment per litre of water-sediment mixture $(\mathrm{mg} / \mathrm{l})$.

Suspended-sediment discharge. The rate at which sediment passes a section of a stream or is the quantity of sediment, as measured by dry weight, or by volume, that is discharged in a given time. When expressed in tons per day, it is computed by multiplying water discharge in cubic feet per second $\left(\mathrm{ft}^{3} / \mathrm{s}\right)$ times the suspended-sediment concentration in milligrams per litre $(\mathrm{mg} / \mathrm{l})$ times the factor 0.0027 .

Tons per day. The quantity of sediment that passes a stream section during a 24-hour day.

Total sediment discharge or total sediment load. The sum of the suspendedsediment discharge and the bedload discharge. It is the total quantity of sediment, as measured by dry weight or volume, that is discharged during a given time.

Water discharge or discharge. The amount of water and sediment flowing in a channel expressed as volume per unit of time. The water contains both dissolved solids and suspended sediment. 


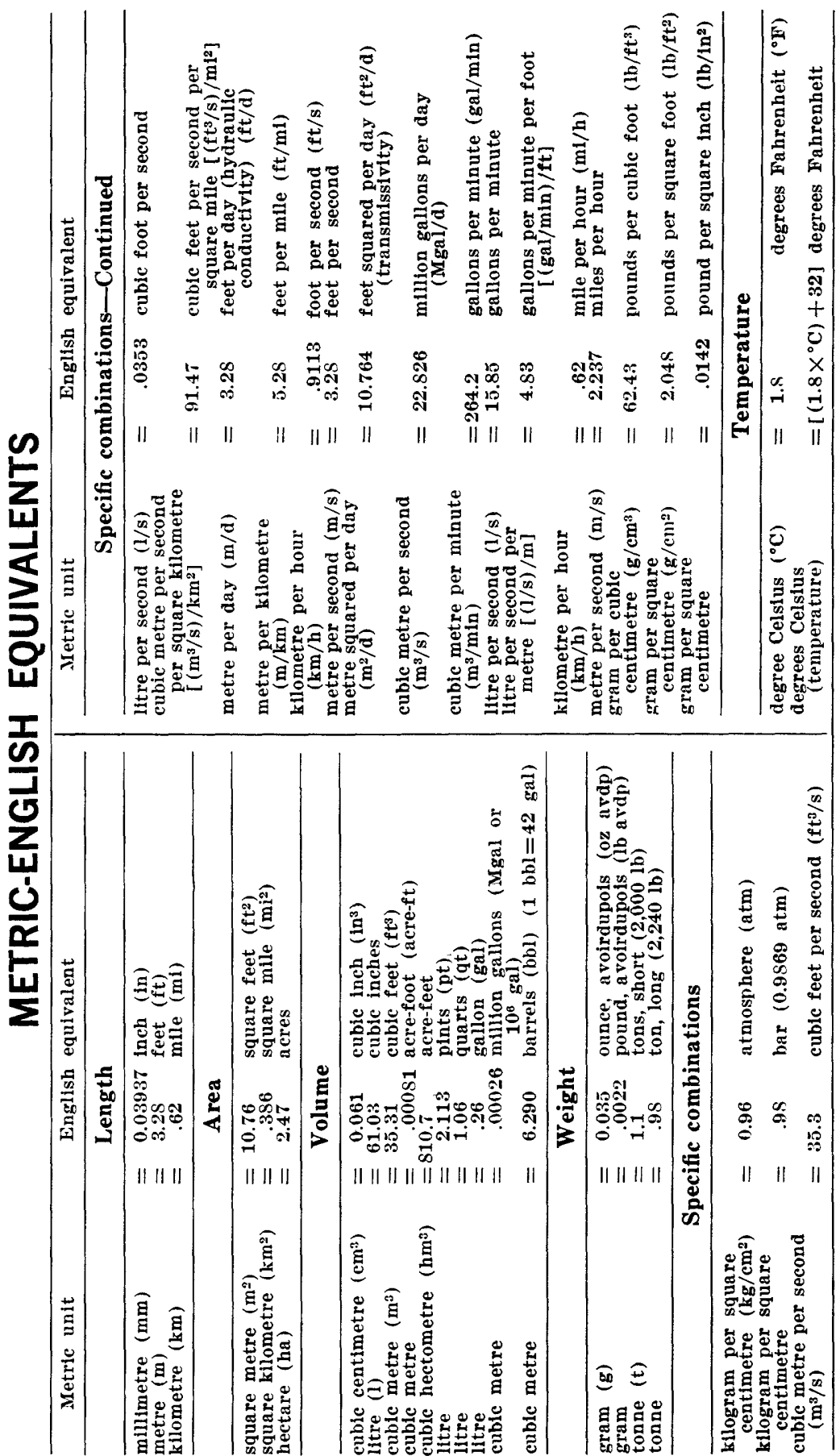


SEDIMENTATION IN SMALL DRAINAGE BASINS

\title{
SEDIMENT CHARACTERISTICS OF STREAMS IN THE EASTERN PIEDMONT AND WESTERN COASTAL PLAIN REGIONS OF NORTH CAROLINA
}

\author{
By Clyde E. Simmons
}

\begin{abstract}
The sediment-transport characteristics of streams were determined in a 15,500-square-kilometre (6,000-square-mile) area of the Coastal Plain and Piedmont regions of eastern North Carolina during 1969-73. The study covered all or parts of 21 counties and included data for 28 sediment-sampling stations in parts of 4 major river basins-the Roanoke, Pamlico, Neuse, and Cape Fear. Annual suspended-sediment yields ranged from 117 to 4.2 tonnes per square kilometre (333 to 12 tons per square mile). Streams in the Piedmont region have the highest yields. Suspended-sediment yield decreases in an eastward direction from the Piedmont to the Coastal Plain region.

Sediment characteristics are directly affected by topography, storm runoff, geology, land use, and man-made detention structures. At one sampling station in the 1973 water year 44 percent of the suspended sediment tonnage was transported during 34 days of high flow. In the Piedmont region, sediment yields vary indirectly with the percentage of forest cover in the basin, but there appears to be no definite relationship between forest cover and sediment yield in the Coastal Plain region. Large lakes act as sediment-detention reservoirs. Average annual sediment yields ranged from 34 to 117 tonnes per square kilometre (98 to 333 tons per square mile) for 3 headwater streams which flow into Hyco Lake in Person County; however, the yield for the station less than 3.2 kilometres ( 2 miles) downstream from Hyco Dam was about 4.2 tonnes per square kilometre (12 tons per square mile).
\end{abstract}

Most suspended sediment during floods in Piedmont streams ranges in size from sand to silt, whereas the suspended material in flooding streams in the Coastal Plain is generally clay size. 


\section{INTRODUCTION}

\section{PURPOSE AND SCOPE}

This report presents the findings of a 5-year study to determine the quantity of suspended sediment transported by streams in a $15,500 \mathrm{~km}^{2}\left(6,000 \mathrm{mi}^{2}\right)$ area of the eastern Piedmont and western Coastal Plain regions of North Carolina. The study was conducted in cooperation with the North Carolina Department of Natural and Economic Resources and was the first attempt in North Carolina to determine areal variations in sediment yield. The results should be of considerable value in future sediment-control programs. This report represents the first of a proposed series of studies intended to define the sediment characteristics of all the major stream basins in the State.

\section{PREVIOUS SEDIMENT STUDIES}

Previous sediment reports have been generally limited in areal coverage and usually concerned with efforts to define the sediment characteristics at a single station or of small basins having special sediment problems. One example is the recent study by the U.S. Geological Survey of erosion and sedimentation at a highway construction site in Wake County (Reeder, 1973), which had a drainage area of only $9.7 \mathrm{hm}^{2}$ (24 acres). Earlier reports by the U.S. Geological Survey, the U.S. Department of Agriculture, and university researchers have usually involved investigations of watershed erosion, reservoir siltation, or other sediment-related problems at particular sites. Watershed work plans prepared by the U.S. Department of Agriculture, Soil Conservation Service, usually include sections pertaining to sedimentation and erosion, but only about 5 percent of the area in this report was covered by the watershed studies.

Malcom (1972) developed a series of curves for determining approximate sediment yields of urban, rural, and severely exposed areas in the Piedmont region of several Atlantic-coast States, including North Carolina.

\section{GENERAL FEATURES OF THE STUDY AREA}

\section{PHYSIOGRAPHY}

The area covered by this report includes parts or all of 21 counties in the eastern Piedmont and western Coastal Plain provinces of North Carolina. (See fig. 1.) Over four-fifths of the study area lies in the Piedmont. 
PIEDMONT AND COASTAL PLAIN, NORTH CAROLINA O3

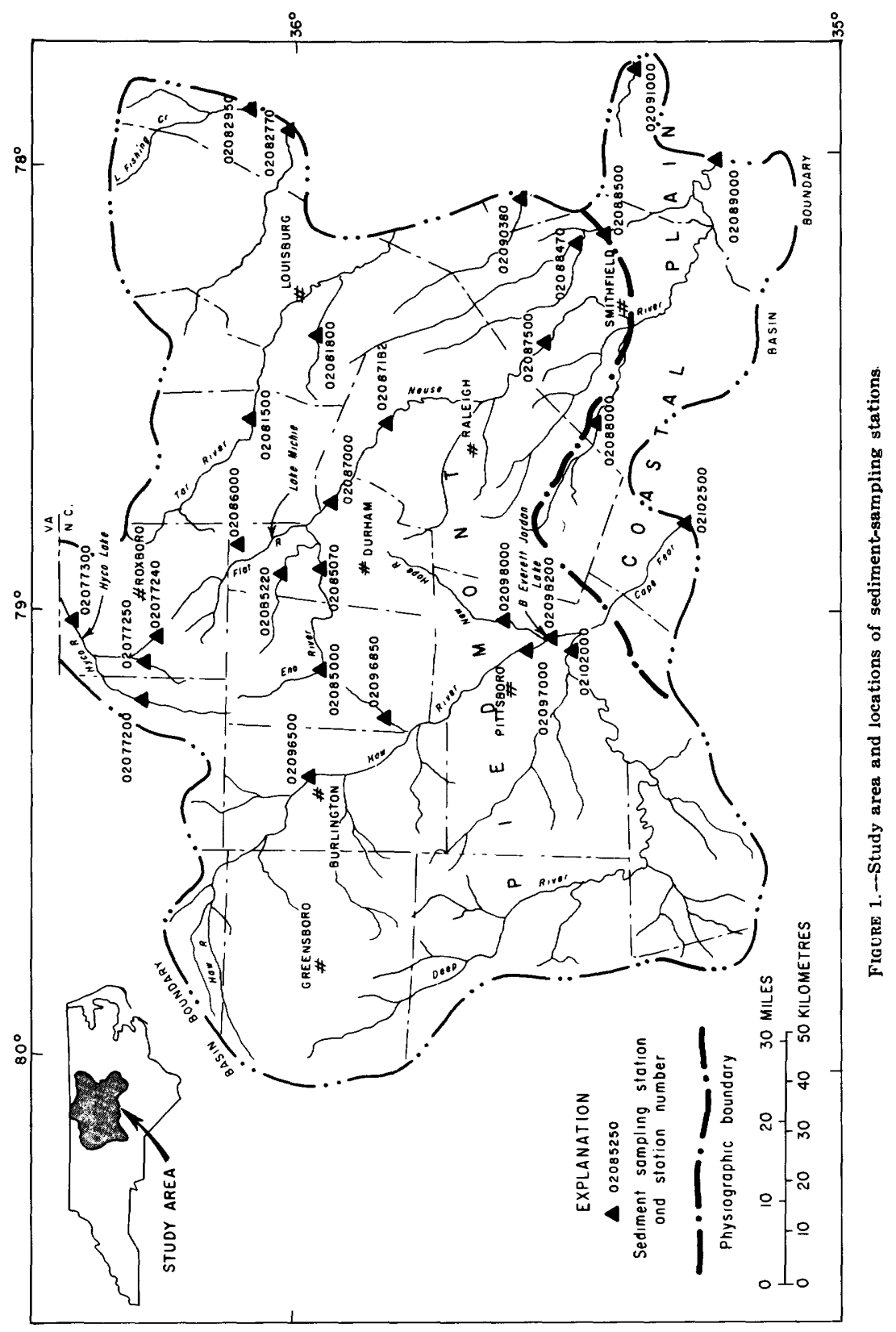


The Piedmont and the Coastal Plain are distinctly different physiographic regions. They are different not only in geologic age, soils, and rocks, but also in altitude above mean sea level and relief. The Piedmont region is characterized by rolling hills, elongated ridges, and valleys which slope gently toward the east or southeast. Land-surface altitudes in the Piedmont part of the area range from more than $300 \mathrm{~m}(1,000 \mathrm{ft})$ above mean sea level in Alamance County to about $90 \mathrm{~m}$ (300 ft) in parts of Wake, Franklin, and Johnston Counties. The part of the area lying in the Coastal Plain is characterized by gently rolling or undulating topography of little relief. Altitudes are considerably lower than those found in the Piedmont and are usually less than $90 \mathrm{~m}(300$ ft) above mean sea level.

Except for several smaller streams in the northern part of the area which flow in a northerly direction, the major streams flow in a southeasterly direction. The study area includes the headwater streams of three of the major rivers in the State-the Cape Fear, Pamlico, and Neuse-and several small tributary streams of the Roanoke River. Stream channels in the Piedmont tend to be narrow and deep, while those in the Coastal Plain are generally much wider and more shallow. Stream gradients of the larger streams in the eastern Piedmont range from about 0.4 to $1.5 \mathrm{~m} / \mathrm{km}$ (2 to 8 $\mathrm{ft} / \mathrm{mi}$ ), whereas those in the Coastal Plain usually have slopes less than $0.6 \mathrm{~m} / \mathrm{km}(3 \mathrm{ft} / \mathrm{mi})$.

\section{GEOLOGY AND SOILS}

Metamorphic rocks and intrusive granite underlie most of the Piedmont; the Coastal Plain is underlain mostly with sand and loosely consolidated rocks of sedimentary origin. A generalized geologic map of the area is shown in figure 2. Most of the metamorphic rocks are gneisses, schists, and metamorphosed ancient volcanic rocks. A long narrow band of Triassic sedimentary rocks, composed mostly of sandstone, conglomerate, siltstone, and shale, strikes in a diagonal northeastern trend across the central part of the area. Sedimentary formations composed generally of quartz sand, gravel, and lenses of clay are predominant in the southeastern part of the area; the contacts of the sedimentary rocks with the metamorphic rocks are generally along the western border of the Coastal Plain province.

Soils in the Piedmont are derived chiefly from the disintegration and weathering of the underlying rock, and range in texture from loamy sand to silty clay loam. Soils from the metamorphosed volcanic rocks are characteristically silty; the granites and gneisses 


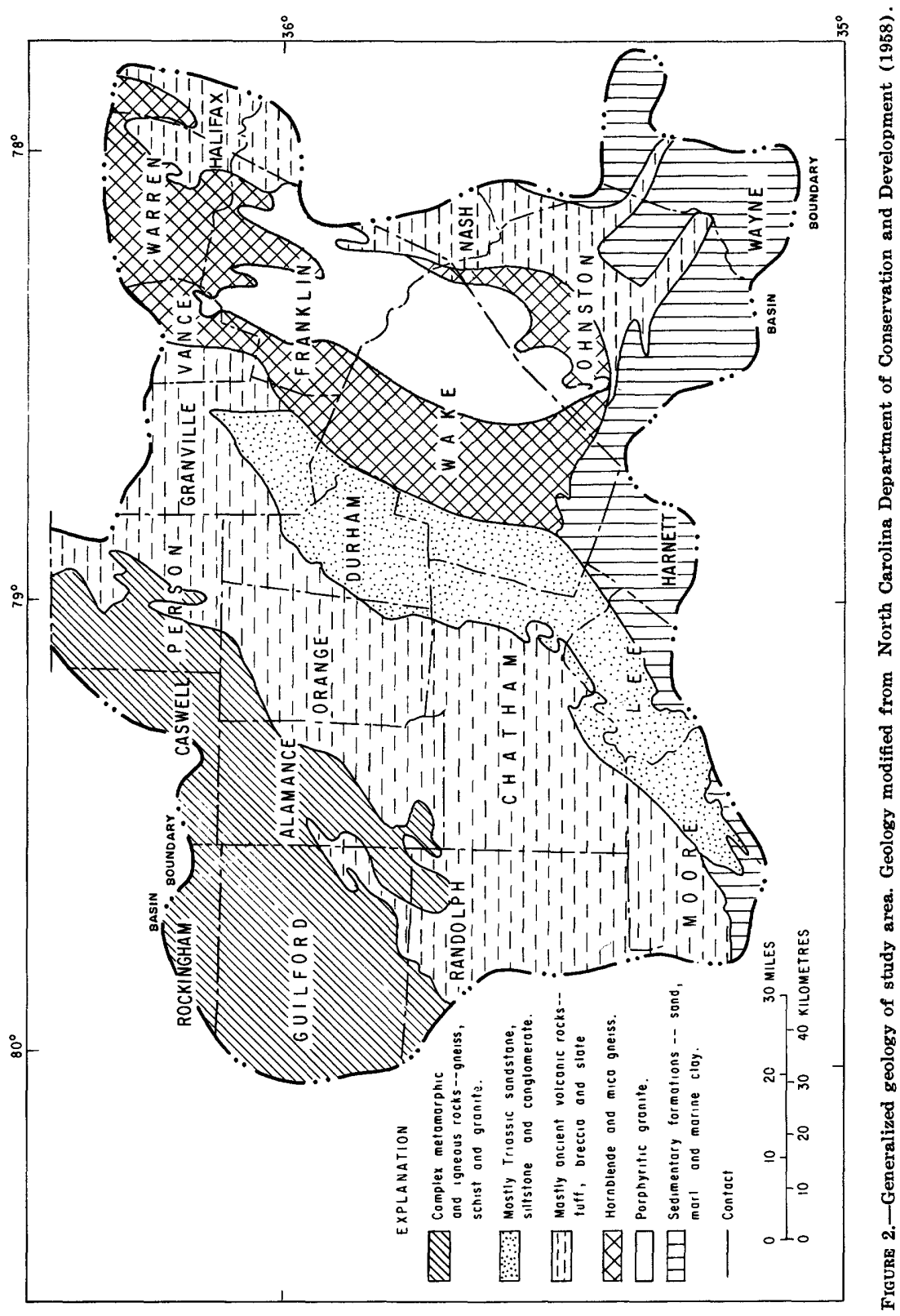


generally produce sandy clay loams, while the schists generally produce silty clay loams (Lee, 1955). The soils of the southeastern part of the study area, which are underlain by formations of sedimentary origin, range in texture from coarse sands to sandy loams.

Soil erodibility is related mainly to the physical characteristics of the soil, such as cohesiveness and grain size, although the intensity of the precipitation and the surface slope are also major factors in the erosional processes. Normally, a sandy soil is considered highly erodible; however, because of its large infiltration capacity, it might be eroded less than a "nonerodible" clay soil on the same slope if the slope is not steep and rainfall intensity is not much greater than the infiltration capacity of the sandy soil. The finer grained materials such as silts and clays are more easily dislodged from the soils by heavy rains and carried away in suspension by surface runoff. Throughout most of the area, water velocities of sheet or surface runoff are not high enough to transport sand-size particles in suspension. This report does not cover in detail the soil characteristics or the mechanics of erosion; however, fluvial sediment is significantly affected by geology and soil properties. Obviously, the many different soil types found in the Piedmont and Coastal Plain contribute to the differences in the sediment characteristics of the streams.

\section{CLIMATE}

Most of North Carolina has a moderate climate. The average July temperature is about $27^{\circ} \mathrm{C}\left(80^{\circ} \mathrm{F}\right)$ and the average for January is about $6^{\circ} \mathrm{C}\left(43^{\circ} \mathrm{F}\right)$ in the study area. There is very little variation in temperature from one point to another during any specific time.

Precipitation is mostly in the form of rain, although a small amount of snow usually falls several times each winter. Precipitation is fairly well distributed throughout the year, but is usually greatest in July and August and least in October and November. High-intensity soil-eroding rains might occur during any month. Graphs showing annual precipitation for 1969-73 and the longterm averages for four cities in the study-area are shown in figure 3. No record-breaking floods or droughts occurred during the 5year study; hydrologically, conditions were generally representative of the long-term averages for the area.

\section{VEGETATION}

The vegetative cover of the area includes a large variety of forms, but the greater part of the area, about 62 percent, is mod- 
erately to heavily forested. The dominant vegetation consists of forest trees with a varying undergrowth of shrubs and smaller plants. Most of the trees are hardwoods and conifers-the conifers being generally the loblolly pine in the eastern part of the area and the shortleaf pine in the western part (Lee, 1955). Pines occupy about 70 percent of the forested areas.

Approximately 33 percent of the study area is used for agricultural purposes, which includes grasslands used for grazing. Grasslands are predominant in the Piedmont, whereas croplands are more predominant in the Coastal Plain region. The four major crops, in decreasing order of harvested acreage, are corn, hay, soybeans, and tobacco.

\section{SEDIMENT CHARACTERISTICS}

\section{METHODS OF SAMPLING AND ANALYSIS}

Suspended-sediment samples were collected using the methods outlined by Guy and Norman (1970). Basically, the procedure involves using either the 10-kg (22-1b) DH-59 sampler or the $28-\mathrm{kg}$ (62-lb) D-49 sampler. The heavier sampler is used in streams having greater depths and velocities. Both are depth-integrating samplers. A suspended-sediment sample is obtained by lowering the sampler at a uniform rate to the bottom of the stream, instantly reversing upon contact with the bottom, and raising to the surface again at a uniform rate.

Sediment concentrations were determined in the U.S. Geological Survey sediment laboratory in Raleigh, N.C., using the methods outlined by Guy (1973). Suspended-sediment concentrations were determined by the filtration method, which involves weighing the sample and filtering, drying, and weighing the sediment. Particle sizes of the suspended sediment for selected samples were determined with sieves, and for particles finer than $0.062 \mathrm{~mm}$ by the bottom-withdrawal tube method.

\section{UNMEASURED SEDIMENT DISCHARGE}

The sediment samplers used in this study do not permit sampling closer than 51 to $102 \mathrm{~mm}$ ( 2 to 4 in) above the stream bottom; therefore, the sediment below this level was not included in the sample analyses. The unmeasured part constitutes primarily the bed-material discharge and a small percentage of the suspended-sediment discharge, and generally represents the larger sizes of sediment which roll or skip along the streambed. An empirical equation (Chang and others, 1965) was used to calculate the bed-material discharge at three representative stations 

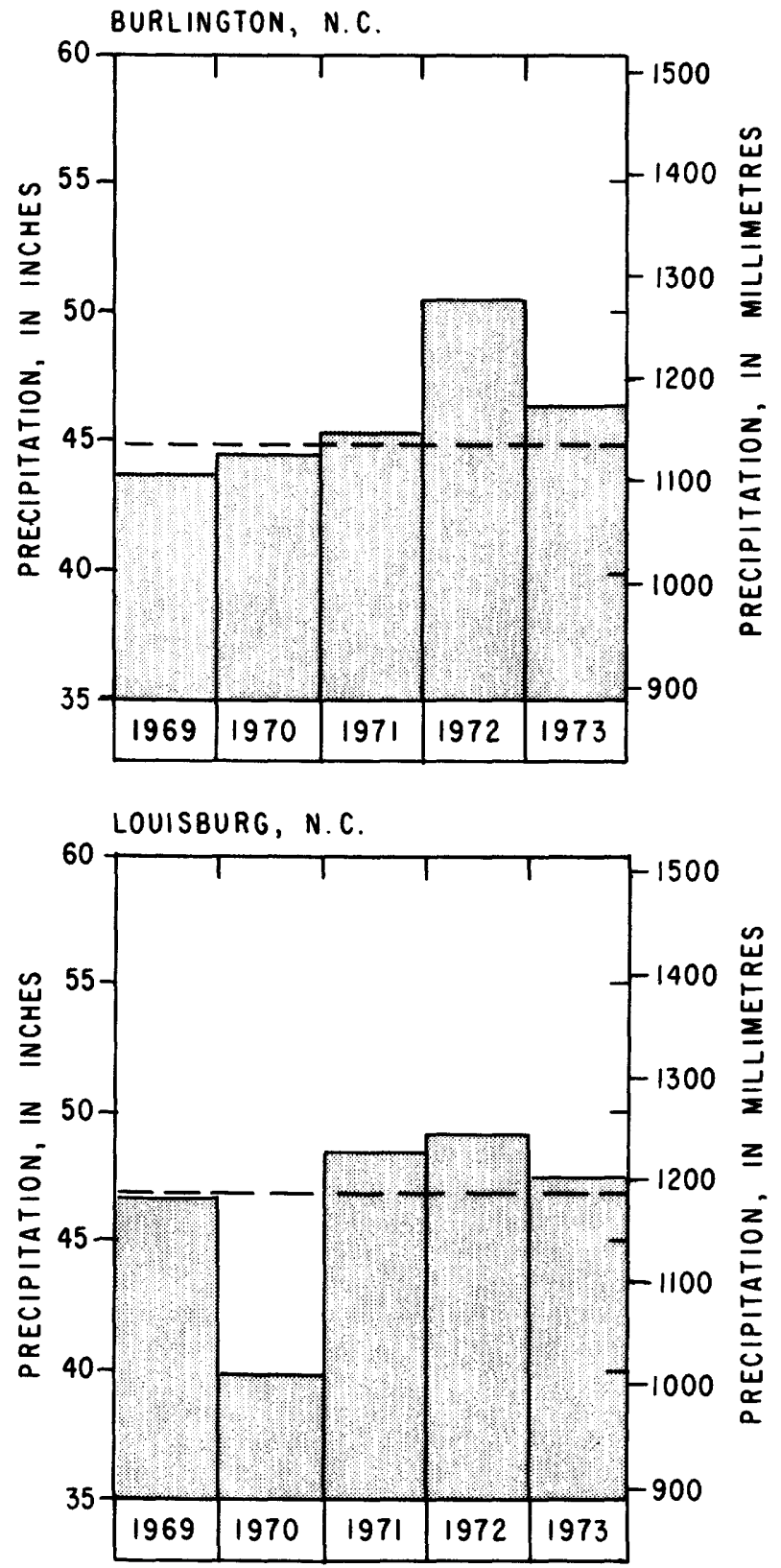

Figure 3.-Comparison of annual precipitation during the study period with long-term averages (dashed line) at selected points. 
PIEDMONT AND COASTAL PLAIN, NORTH CAROLINA 09
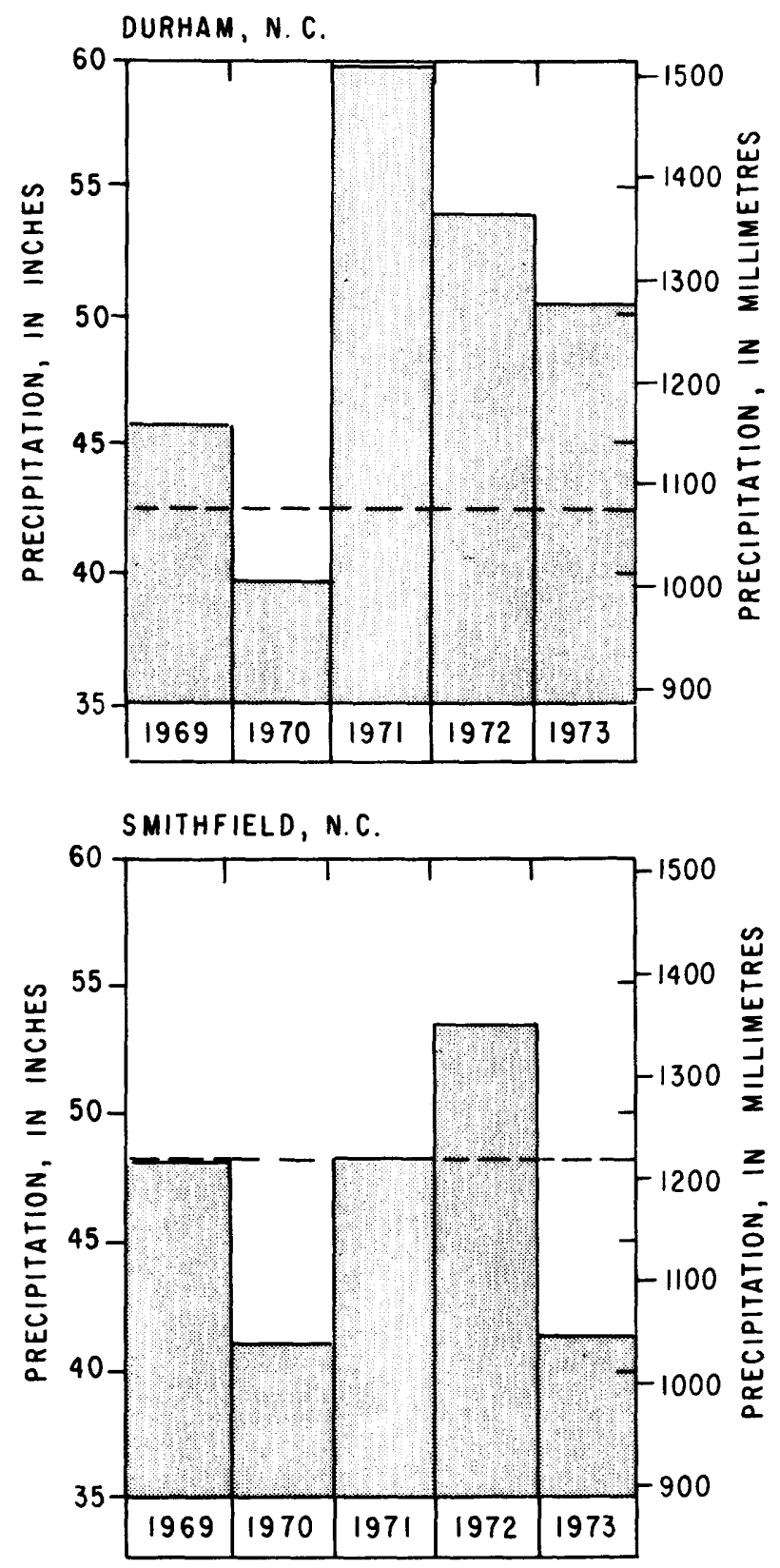

Figure 3.-Continued. 
because there is no accurate way as yet to measure the amount of sediment transported in this zone. The computed values ranged from 1 to 4 percent of the suspended-sediment discharge. Lack of sufficient data, however, prevented the computing of bedloads for all of the study sites. Because the unmeasured sediment discharge apparently represents such a small percentage of the total, only suspended-sediment data are given in this report, and no attempt was made to include the unmeasured part.

\section{METHOD OF GOMPUTATIONS}

In most streams, a relation exists between water discharge and suspended-sediment discharge. This relation is generally expressed as an average curve or sediment-transport curve.

The computations of average annual suspended-sediment discharge given in this report were determined by the sedimenttransport flow-duration curve method described by Miller (1951) and Colby (1956). Field values of instantaneous suspended-sediment data used in this study have previously been published (U.S. Geological Survey, 1969-73).

Instantaneous sediment samples were collected periodically at the sampling stations. Although each station was equipped for recording continuous streamflow, sediment samples were obtained only at a minimal frequency to allow definition of the suspendedsediment characteristics through a full range of stages at the station. Thus, samples were collected at low, medium, and high stages. The suspended-sediment concentration of each sample was converted to suspended-sediment discharge. Specifically, the conversion is as follows:

where

$$
Q_{s}=0.0027 C Q
$$

$Q_{s}=$ Instantaneous suspended-sediment discharge, in tons per day,

$C=$ Concentration of sediment, in milligrams per litre, and

$Q=$ Instantaneous water discharge, in cubic feet per second.

Suspended-sediment discharges were then plotted on log-log paper versus the corresponding water discharges to develop a sediment-transport curve for each station. Flow-duration curves, showing the percentages of time that discharges equal or exceed certain rates, were also developed for each station for the 196973 water years. Following development of the above two curves, calculation of the average annual sediment discharge for each station was computed as follows, using the Eno River near Durham as an example. 
1. Using the station flow duration curve (fig. 4), water discharges were determined for the corresponding percentages of time shown in column 1 of table 1.

2. The corresponding sediment discharges were determined from the sediment-transport curve (fig. 5) as shown in column 3 of table 1.

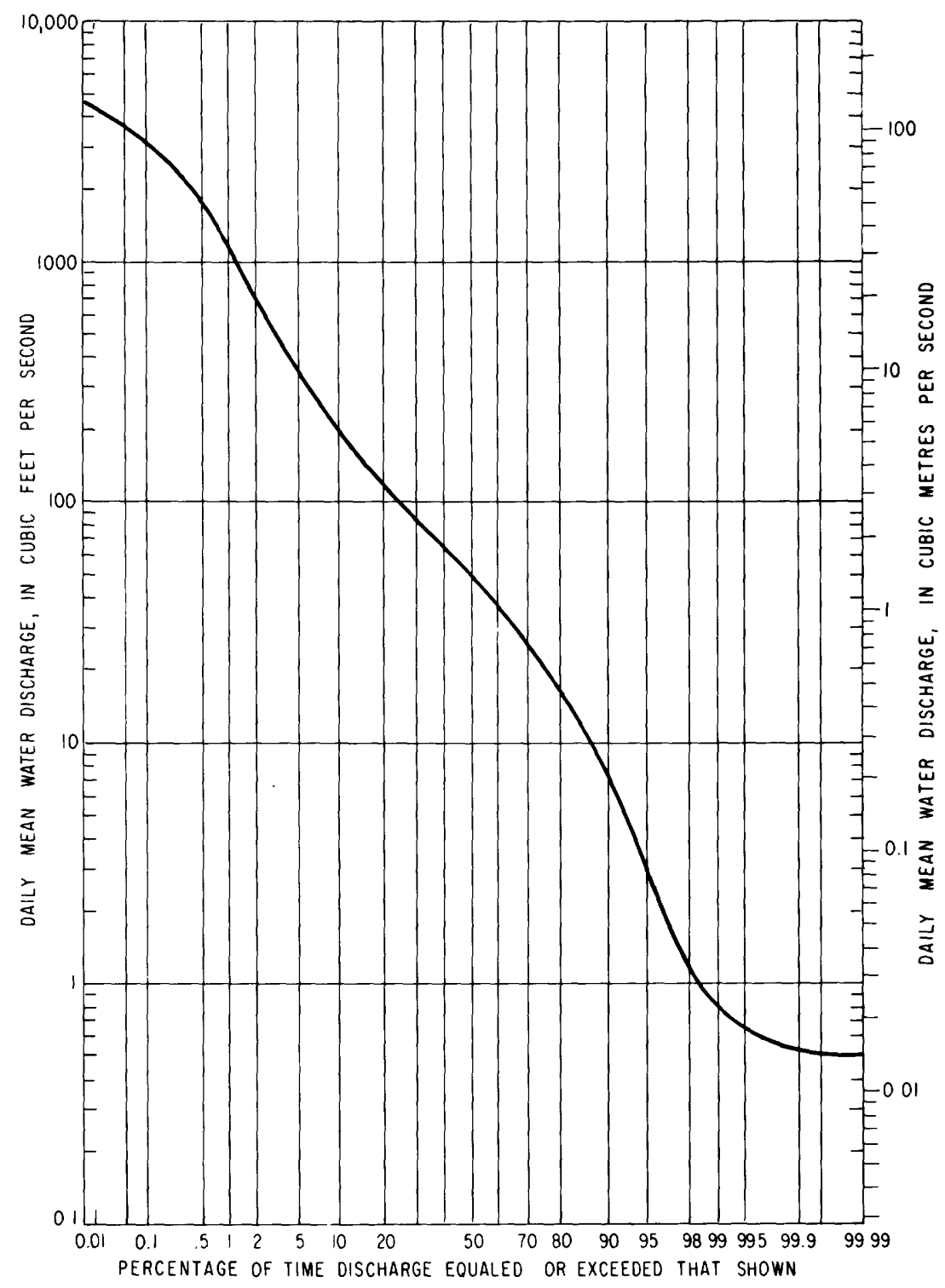

Figure 4.-Duration curve of daily mean discharge of Eno River near Durham, 1969-73 water years. 
TABLE 1.-Computations of average annual suspended-sediment yield of the Eno River near Durham, 1969-73

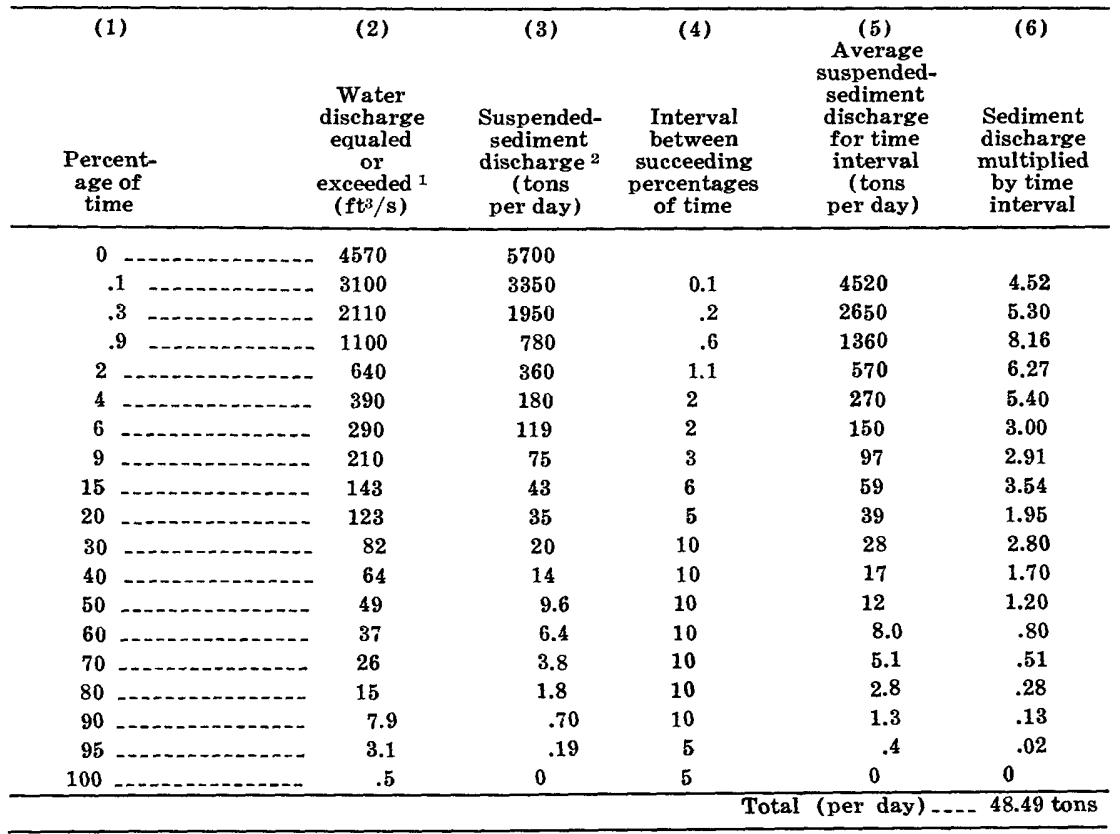

Nore.-Average annual suspended-sediment discharge $=365 \times 48.49=17,700$ tons or $16,100 \mathrm{t}$ Drainage area of basin $=141 \mathrm{mi}^{2}$ or $365 \mathrm{~km}^{2}$

Average annual sediment yield $=17,700 \div 141=126$ tons $/ \mathrm{mi}^{2}$ or $44 \mathrm{t} / \mathrm{km}^{2}$

1 Computed from figure 4.

2 From figure 5 .

3. Average sediment discharges were then computed from the sediment discharges in column 3 by averaging the discharges at the limits of each time interval.

4. Each average sediment discharge was multiplied by the corresponding time interval to give the sediment discharge representative of that percentage of the total time.

5. The incremental sediment discharges in column 6 were then totaled to give the average suspended-sediment discharge in tons per day for the station. This figure multiplied by the number of days in a year (365) gives the average yearly sediment discharge in tons per year. The sediment yield per unit of area at the station was then determined by dividing the average yearly figure by the area of the drainage basin (in square miles), resulting in a yield having units of tons per square mile per year.

It is suggested that the data within this report be used only with due consideration to the following implied accuracy. The 
INSTANTANEOUS WATER DISCHARGE, IN CUBIC METRES PER SECOND

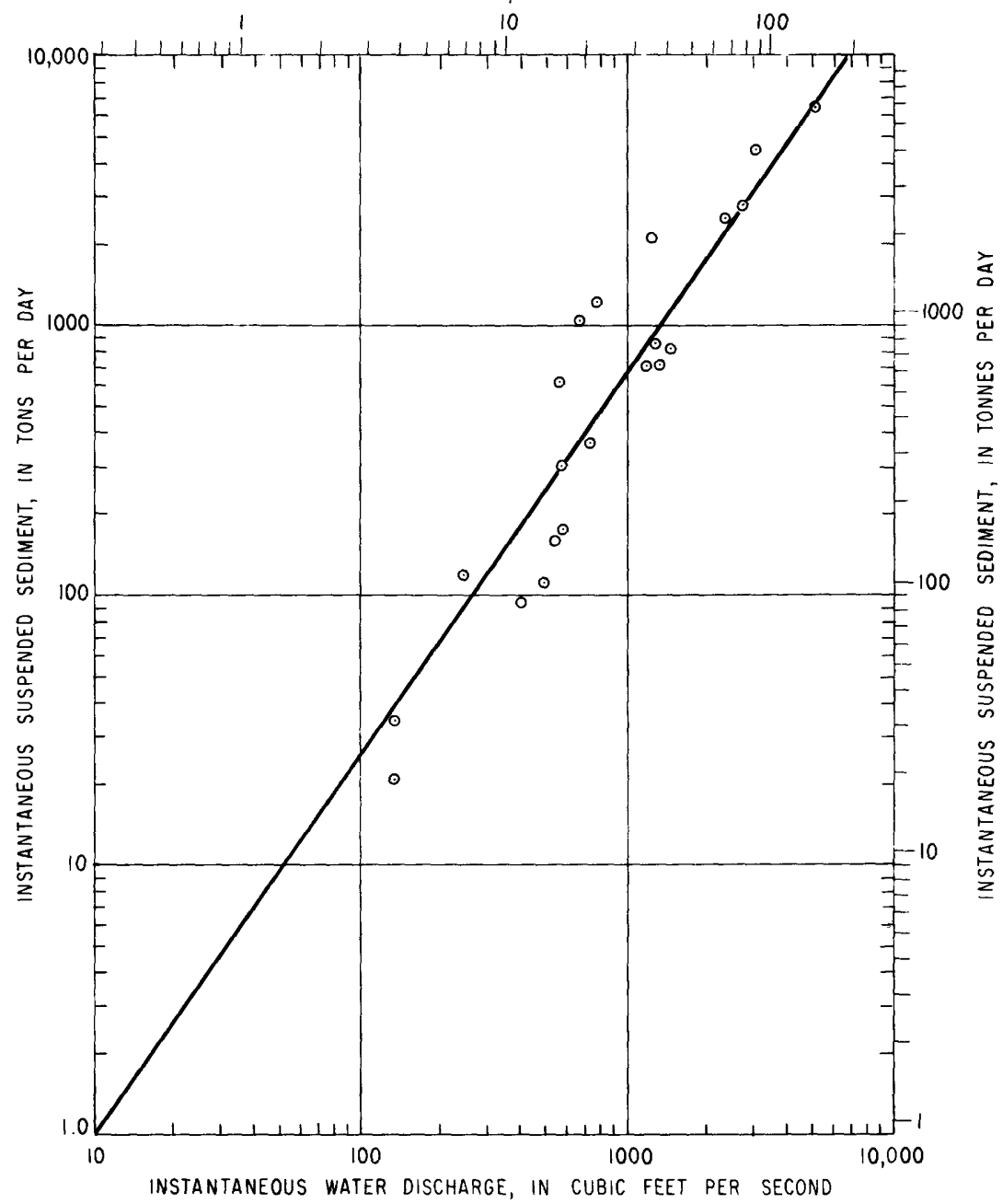

Figure 5.--Sediment-transport curve for Eno River near Durham, 1969-73 water years.

extreme upper ends of most of the sediment-transport curves were defined by only a few measurements, and in some cases these extremes were estimated by simply extending the curve to cover the desired range. For most applications, however, this method has proven to be satisfactory (Colby, 1956, and Miller, 1951), and the data herein are believed to be indicative of the actual sediment characteristics of the various stream basins.

Studies in other States have shown that the above method of computing long-term sediment yields is usually reliable within $\mathbf{5}$ to 20 percent for most streams. Because this represents the first 
study in North Carolina to use the method extensively, a comparison was made between the yield computed from the flowduration sediment-rating curve method and the yield as determined from daily sediment samples at the sampling station, Yadkin River near Yadkin College. The Yadkin College station, which is in the central Piedmont and not in the study area, was used for comparison because it is the only daily sediment station in the State. At this station, suspended-sediment samples are collected daily during normal flow and several times each day during periods of high flow. A mean daily suspended-sediment concentration is determined from the analysis of each sample, and a suspendedsediment discharge (in tons) for each respective day is computed. The annual suspended-sediment discharge is the summation of the daily data for the desired year. The computation of annual sediment data using daily values is widely accepted as the most accurate and practical method in use. In order to compare results obtained from the above daily method with those obtained by the sediment-rating curve method, a flow duration curve, as shown in figure 4, was developed for the Yadkin College station for the period 1969-73. Next, approximately 10 suspended-sediment discharges representing a fair range of flow conditions were picked at random from each year and plotted as in figure 5. Using the method of least squares, a curve of best fit was drawn through the plotted points to form the sediment-rating curve, and an average annual suspended-sediment yield was computed by the method used in table 1 . The results of the comparison are given in table 2. Notice that the difference in yields computed by the two methods for the 5-year period is less than 2 percent, but this close agreement should not generally be expected.

TABLE 2.-Comparison of sediment yields at Yadkin River near Yadkin College using the sediment-rating curve method and daily sediment samples

\begin{tabular}{|c|c|c|}
\hline & $\begin{array}{l}\text { Data computed from } \\
\text { daily samples }\end{array}$ & $\begin{array}{l}\text { Data computed } \\
\text { using curve method }\end{array}$ \\
\hline \multicolumn{3}{|l|}{ Sediment discharge- } \\
\hline $1969 \mathrm{WY}$ (water year) & 575,400 tons & \multirow{5}{*}{$5,261,000$ tons } \\
\hline $1970 \mathrm{WY}$ & 703,100 tons & \\
\hline 1971 WY & 942,700 tons & \\
\hline 1972 WY & $1,477,000$ tons & \\
\hline 1973 WY & $1,491,800$ tons & \\
\hline Total for period & $5,190,000$ tons & $5,261,000$ tons \\
\hline $\begin{array}{l}\text { Average yearly sediment } \\
\text { discharge for period.- }\end{array}$ & $1,038,000$ tons $/ y r$ & $1,052,200$ tons $/ y r$ \\
\hline Drainage area & $2,280 \mathrm{mi}^{2}$ & $2,280 \mathrm{mi}^{2}$ \\
\hline Sediment yield & $455\left(\right.$ tons $\left./ \mathrm{mi}^{2}\right) / \mathrm{yr}$ & $461\left(\right.$ tons $\left./ \mathrm{mi}^{2}\right) / \mathrm{yr}$ \\
\hline
\end{tabular}




\section{SUSPENDED-SEDIMENT CONCENTRATIONS AND YIELDS}

Natural suspended-sediment concentrations in streams vary mainly according to soil type, soil cover, slope, stream discharge, and intensity of precipitation. Streams draining the Piedmont, where slopes and stream velocities are generally greater than those in the Coastal Plain, transport higher concentrations of sediment. Short periods of heavy runoff during storms are responsible for the major part of sediment transport during most years, although these storm periods usually represent only a small percentage of the total time. Throughout the study area, sediment concentrations varied directly with streamflow and surface runoff - low flows produced low or negligible amounts of sediment and flood flows produced large amounts.

The proportion of suspended sediment transported by floods can be demonstrated by using the daily sampling station on the Yadkin River at Yadkin College. During the 1973 water year, 9 high-flow periods totaling 34 days transported 596,000 tonnes (657,000 tons) of sediment past Yadkin College. Although this period represents only 9 percent of the water year, the sediment transported was more than 44 percent of the yearly total.

Suspended-sediment yield data are rarely, if ever, identical for different sampling points in an area. Because the yield is computed by dividing the mean annual suspended-sediment discharge by the size of the drainage area, the result is an average yield for that part of the basin above the point of sampling. Obviously, because of the many areal variations within the larger basins-such as differences in topography, vegetative cover, geology, and so forth-average yields might vary significantly from one point to another within the same basin. The average annual suspendedsediment yields are shown in figure 6 and table 3. Although the yield data shown in table 3 are reliable for the respective sedimentsampling stations, data obtained from the sediment-yield map by interpolation should be used as estimates only.

As a guide to the range in suspended-sediment concentratior.s that might occur at the sampling sites, table 3 and figure 7 show approximate concentrations equaled or exceeded 1 percent and $\mathbf{5}$ percent of the time. Many of the low-flow data points were ol)tained by interpolation and straight-line extension of concentriztion data for slightly higher flows; therefore, these data, also, should be used as estimates only.

\section{EFFECTS OF LAND USE ON SUSPENDED SEDIMENT}

Within the last several years, increased interest has been placed on the role that land use-such as urban developments, strip- 


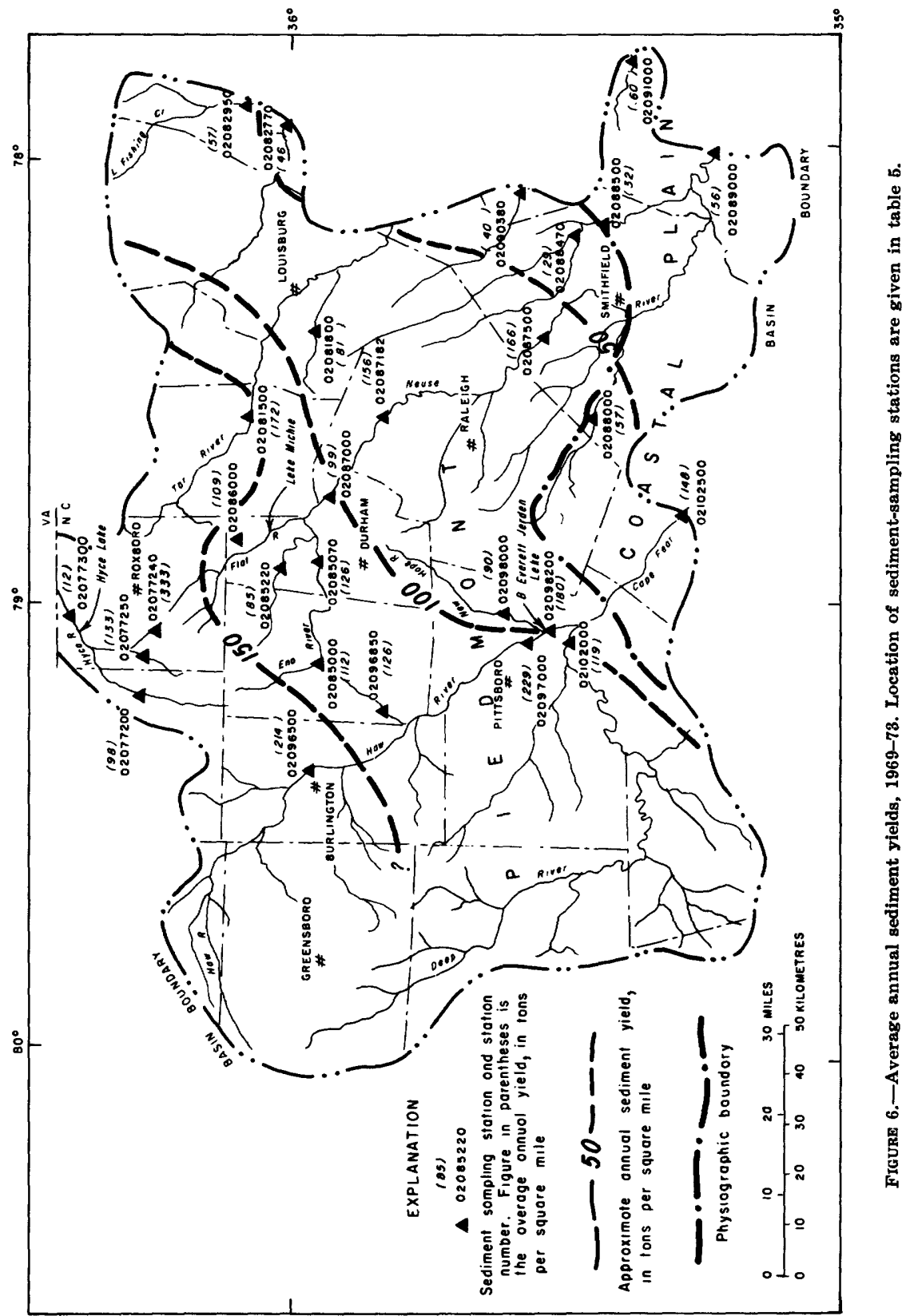




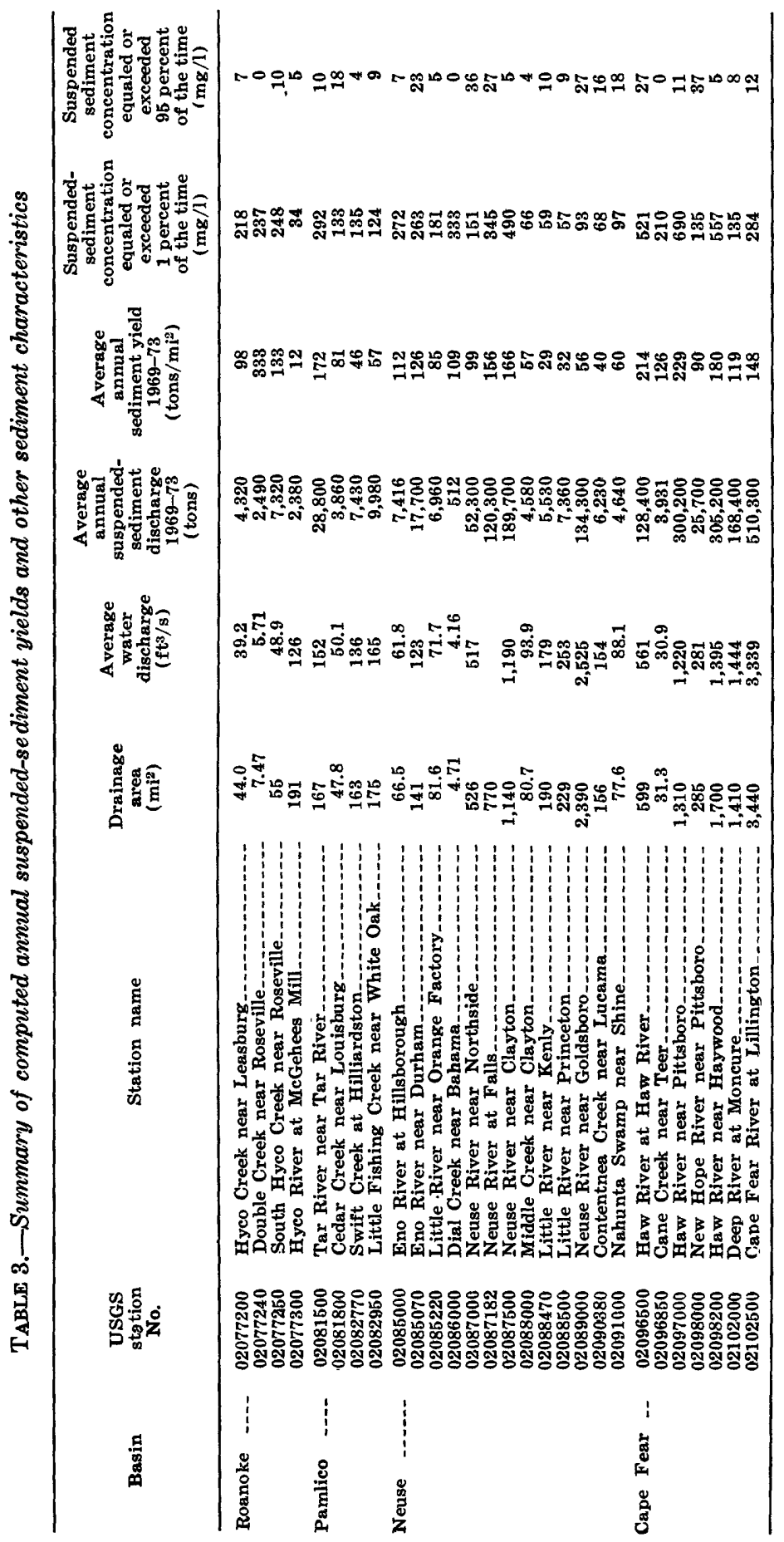


cutting of forest lands, poor farming practices, and large-scale disturbances of natural vegetation (ground cover) - plays in erosion. Estimates by the Soil Conservation Service (U.S. Dept. Agriculture, 1965) indicate that, on the average, gross soil erosion in the eastern United States is about $11 \mathrm{t} / \mathrm{hm}^{2}$ ( 5 tons per acre) per year from croplands, about $4 \mathrm{t} / \mathrm{hm}^{2}$ ( 2 tons per acre) per year from pastureland, and about $1 \mathrm{t} / \mathrm{hm}^{2}$ ( 0.5 ton per acre) per year from forest land. It is further estimated that about 30 to 40 percent of these eroded soils become waterborne sediment in streams. Other reports show that staggering amounts, in some cases hundreds of times larger than the above losses, have been eroded from large construction areas such as highways (Reeder, 1973) and urban development (Guy, 1960). Usually, however, these high sediment-yield areas are small in comparison to the total stream basin, and therefore have little effect on the suspended-sediment yields of large streams.

Land use was determined for the drainage basins above most sampling stations in the study area. Topographic maps, having scales of $1: 24,000$ or $1: 62,500$, showing woodland overprint were used to calculate percentages of agricultural land, forest cover, and urban and small-lake areas (see table 4). These land-use data are in general agreement with data published recently for North Carolina by the Soil Conservation Service (U.S. Dept. Agriculture, 1967), although the latter are tabulated by county and not by stream basin. A comparison of the percentage of forest cover versus average annual yield is shown in figure 8 . In the Piedmont region, the annual sediment yield varies indirectly with the percentage of forest cover, whereas the data for the Coastal Plain area does not show any obvious relationship (except that all Coastal Plain data show less annual suspended-sediment yield).

As shown in table 4, urban areas generally occupy less than 8 percent of the area in the drainage basins; thus, most of the basins can be considered as essentially rural. A comparison of sediment yields versus percentages of urban areas does not show any relationship.

\section{MAJOR RIVER BASINS}

ROANOKE RIVER BASIN

Four sampling sites were in the Roanoke River basin. ${ }^{1}$ The sites, with a combined total drainage area of less than $518 \mathrm{~km}^{2}(200$ $\mathrm{mi}^{2}$ ) were in the heauwaters and main stem of the Hyco River.

\footnotetext{
${ }^{1}$ For the convenience of the reader, the location of each sampling site used in this study is given in table 5 .
} 
PIEDMONT AND COASTAL PLAIN, NORTH CAROLINA 019

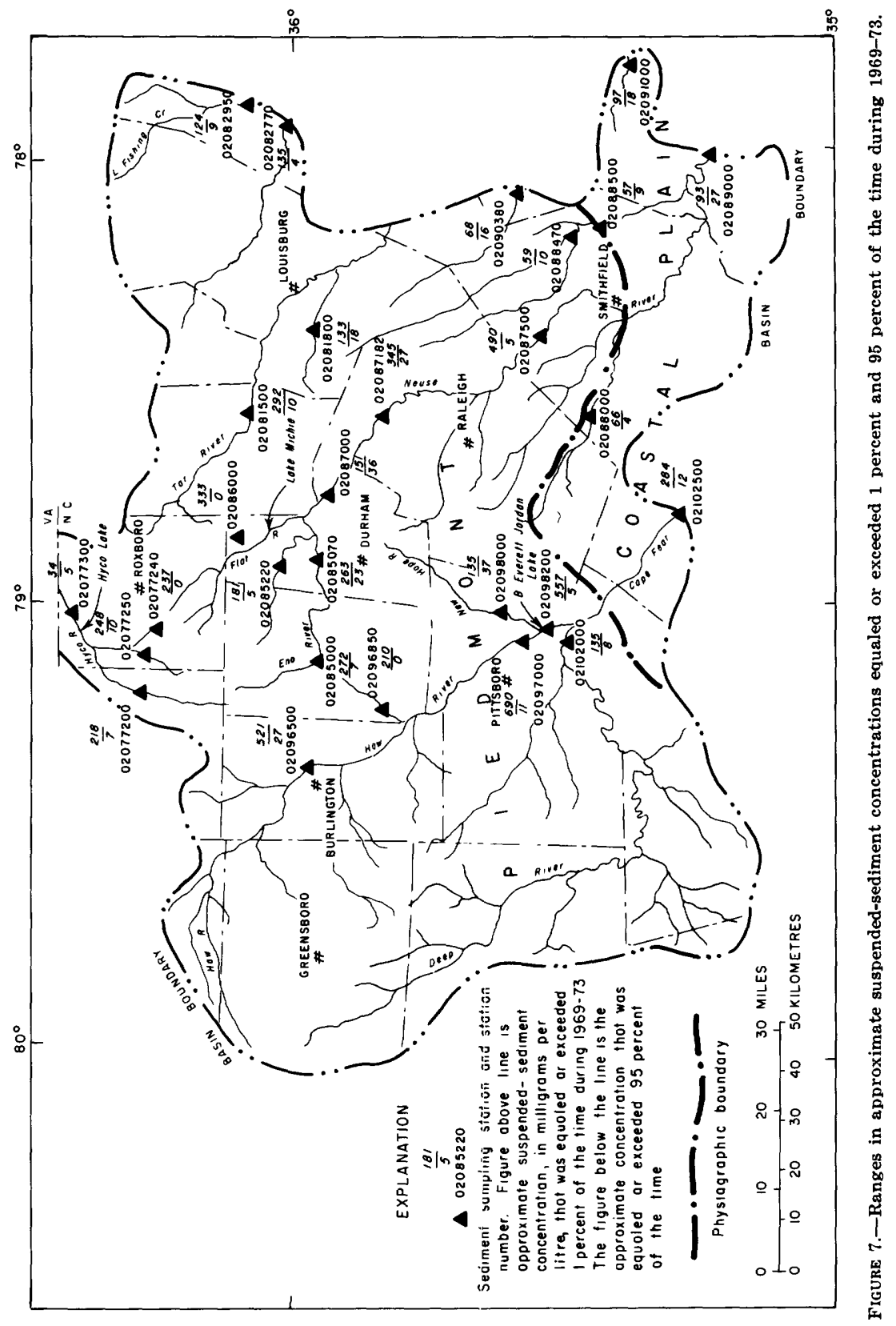


TABLE 4.-Summary of land use of the subbasins

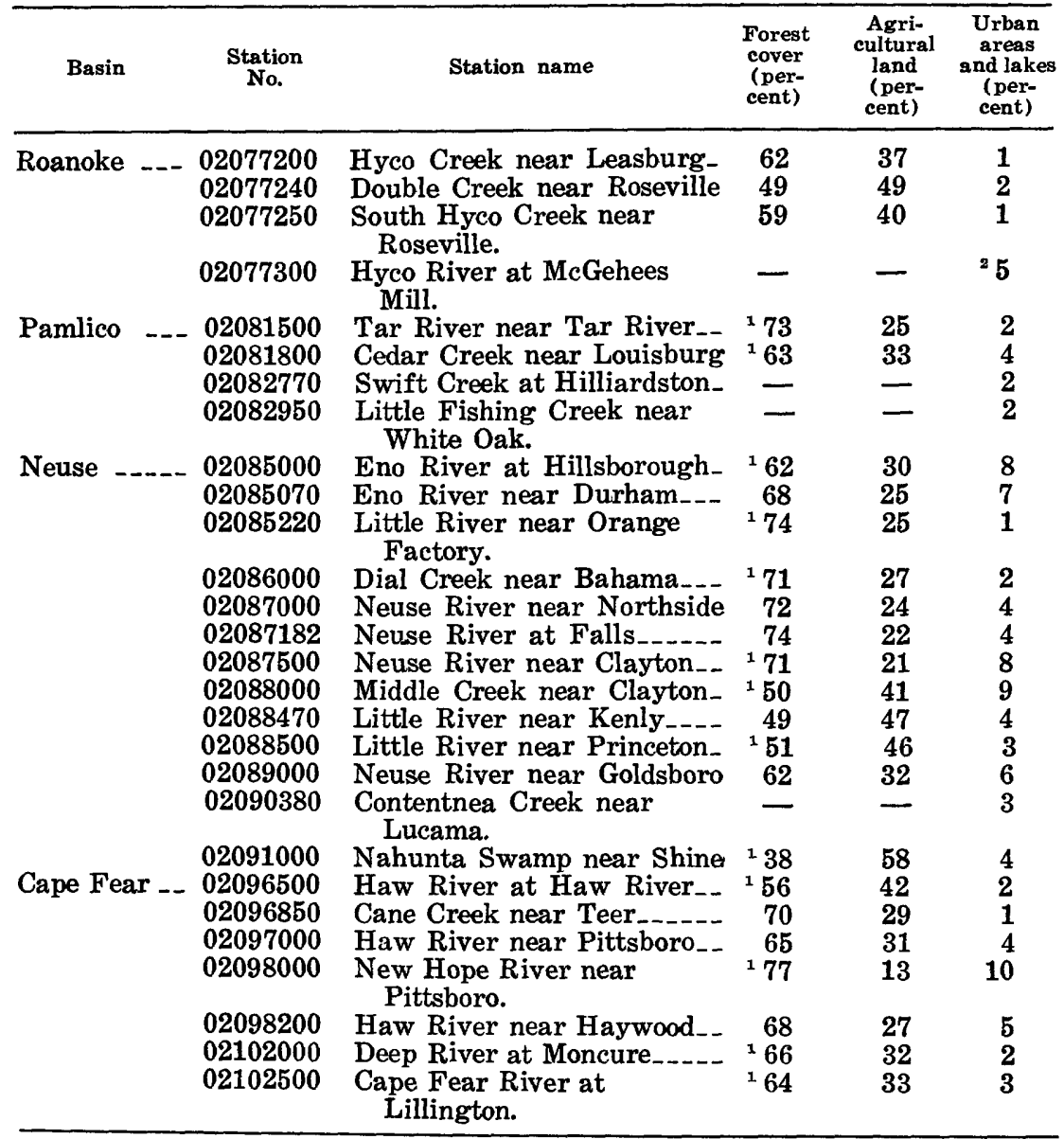

1 Goddard and others (1970).

2 About 4 percent of the area is covered by Hyco Lake and powerplant installation.

The area is sparsely populated and is characterized by rugged, hilly topography, rapid-runoff conditions, and soils composed mostly of sandy-clay loams. Forests cover more than 50 percent of this part of the Hyco River basin, and only about 1 percent is urbanized. Carolina Power and Light Company's huge Hyco Lake and power plant cover almost 4 percent of the basin. Measured suspended-sediment concentrations at the sampling sites ranged from negligible at low flows to more than $1,500 \mathrm{mg} / \mathrm{l}$ during floods at Double Creek near Roseville.

The $1,760-\mathrm{hm}^{2}$ (4,350-acre) Hyco Lake acts as a highly efficient sediment trap. The average annual yields for the three stations up- 
PIEDMONT AND COASTAL PLAIN, NORTH CAROLINA O21

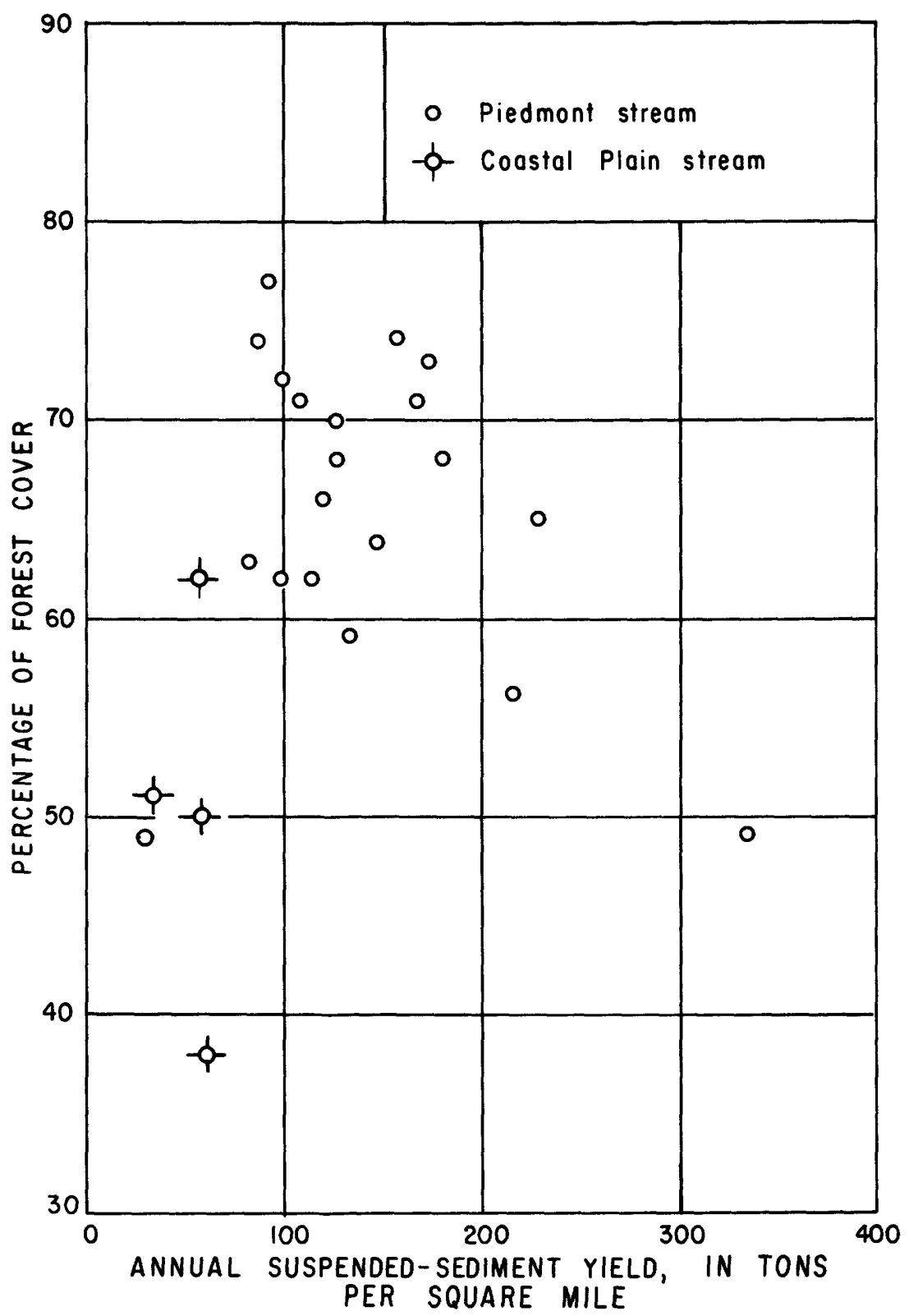

Figure 8.-Relation of percentage of forest cover and average annual suspended-sediment yield for sediment stations.

stream from the lake ranged from 34 to $117 \mathrm{t} / \mathrm{km}^{2}$ (98 to 333 tons $/ \mathrm{mi}^{2}$ ) whereas the suspended-sediment yield for the Hyco River station $2.7 \mathrm{~km}$ (1.7 mi) downstream from the lake was only 
$4.2 \mathrm{t} / \mathrm{km}^{2}$ (12 tons $\left./ \mathrm{mi}^{2}\right)$. Thus, the quiescent waters of the lake cause most of the suspended sediment to settle out of the water and thereby prevent the normal downstream continuity of sediment movement. The drainage area of Hyco Lake is $490 \mathrm{~km}^{2}(189$ $\mathrm{mi}^{2}$ ) ; therefore, assuming an estimated annual suspended-sediment yield of $39 \mathrm{t} / \mathrm{km}^{2}$ (110 tons $/ \mathrm{mi}^{2}$ ) as an average for the basin, minus about 10 percent of which flows through the lake in suspension, the lake trapped approximately 19,000 tons (about 9 acrefeet) or $17,000 \mathrm{t}\left(0.01 \mathrm{hm}^{3}\right)$ of sediment per year during the study period.

\section{PAMLICO RIVER BASIN}

The study area includes four sampling stations in the upper Pamlico River basin. The stations are fairly widely separated and do not adequately define the sediment characteristics of the basin. The upper-headwaters station on the Tar River near Tar River is in a Piedmont area marked by steep slopes, rolling topography, rapid runoff, and fairly erodible soils derived primarily from ancient volcanic rocks and formations of sand and clay. The station on Cedar Creek near Louisburg has about the same general physical characteristics except that land slopes are somewhat less, and the soils are derived from granitic and gneissic rocks, which probably accounts for part of the big difference in sediment yields of the two stations. The average annual suspended-sediment yield at the Tar River station was more than twice that for Cedar Creek, 60 and $28 \mathrm{t} / \mathrm{km}^{2}$ (172 and 81 tons $/ \mathrm{mi}^{2}$ ) respectively.

The remaining two sampling stations in the Pamlico basin, Swift Creek at Hilliardston and Little Fishing Creek near White Oak, are near the eastern extremity of the Piedmont. The physical characteristics of the area are more similar to those found in the Coastal Plain region; soils are sandy and highly permeable; surface slopes are gentle, and stream gradients are low. These basin properties have resulted in small suspended-sediment concentrations and annual yields of less than $21 \mathrm{t} / \mathrm{km}^{2}$ ( 60 tons $\left./ \mathrm{mi}^{2}\right)$.

During the study period, suspended-sediment concentrations ranged from essentially negligible at all four stations during extreme low flows to about $450 \mathrm{mg} / \mathrm{l}$ during high flow at the Tar River station.

\section{NEUSE RIVER BASIN}

Thirteen sampling stations were in the upper Neuse River basin. The Neuse River originates in the north-central part of the report area and drains diagonally to the southeast. This part of the Neuse 
basin, about $6,200 \mathrm{~km}^{2}\left(2,400 \mathrm{mi}^{2}\right)$ accounts for nearly 40 percent of the total study area. The northern or upstream two-thirds of the drainage area covered in the study lies in the Piedmont, and the downstream part is in the Coastal Plain and the Fall Zone (the transitional region between the Piedmont and Coastal Piain).

In the upper Neuse headwaters, average annual suspendedsediment yields were similar for Eno River at Hillsborough and Eno River near Durham, 39 and $44 \mathrm{t} / \mathrm{km}^{2}$ (112 and 126 tons $/ \mathrm{mi}^{2}$ ) respectively. The stations on Little River near Orange Factory and Dial Creek near Bahama had lesser yields of 30 and $38 \mathrm{t} / \mathrm{km}^{2}(85$ and $109 \mathrm{ton} / \mathrm{mi}^{2}$ ), respectively. These four stations are in areas with similar geologic and topographic characteristics; however, the yields at the Eno River stations were probably caused to a great degree by differences in land use in the tributary basins. In the Eno River basin, about 68 percent of the area is under forest cover, 25 percent is agricultural land, and 7 percent is urban. In contrast, the Little River and Dial Creek basins are more than 70 percent forested, and urban areas account for less than 2 percent of both basins.

The decrease in yield further downstream on the main stem of the Neuse River near Northside might be attributed to the diluting effects of the less sediment-laden Little River and also to the retention of some of the sediment by Lake Michie, a $194 \mathrm{hm}^{2}$ (480 acre) lake on the Flat River about $16 \mathrm{~km}(10 \mathrm{mi})$ upstream. As the Neuse River meanders across the lower Piedmont, annual suspended-sediment yields increased again to an average of $55 \mathrm{t} / \mathrm{km}^{2}$ $\left(156 \mathrm{tons} / \mathrm{mi}^{2}\right)$ at the Falls station and $58 \mathrm{t} / \mathrm{km}^{2}\left(166 \mathrm{tons} / \mathrm{mi}^{2}\right)$ at the sampling station near Clayton. Yields are dramatically reduced by the lesser surface slopes and changes in soils as the Neuse flows through the Coastal Plain region, dropping to $20 \mathrm{t} / \mathrm{km}^{2}$ (56 tons/ $\mathrm{mi}^{2}$ ) at the Goldsboro station. Tributary streams entering the Neuse in the Coastal Plain region have a significant diluting effect because of their lower suspended-sediment concentrations. During the study period, average annual yields of these tributary streams ranged from $10 \mathrm{t} / \mathrm{km}^{2}\left(29 \mathrm{tons} / \mathrm{mi}^{2}\right)$ for the Little River station near Kenly to $21 \mathrm{t} / \mathrm{km}^{2}$ (60 tons $/ \mathrm{mi}^{2}$ ) for Nahunta Swamp near Shine.

\section{CAPE FEAR RIVER BASIN}

Sediment characteristics and suspended-sediment yields are highly variable in the upper Cape Fear River basin. Because of the rolling topography, steep slopes, and easily eroded soils in the Haw River basin, the average annual sediment yields are among the 
highest in the study area. These values ranged from about 80 $\mathrm{t} / \mathrm{km}^{2}$ (229 tons $/ \mathrm{mi}^{2}$ ) for the sampling station on the Haw River near Pittsboro to about $32 \mathrm{t} / \mathrm{km}^{2}$ (90 tons $/ \mathrm{mi}^{2}$ for the New Hope River near Pittsboro. The decrease in yield on the Haw River between the Pittsboro and Haywood sampling stations (table 3) is believed to be partly attributable to the diluting effect of inflow from the New Hope River, which has a considerably lower sediment yield and enters the Haw River about midway between the two stations. There was also an unknown and highly variable effect on sediment concentrations caused by construction activities at the B. Everett Jordan Dam site, which is on the Haw River about $0.3 \mathrm{~km}(0.2 \mathrm{mi})$ downstream from the confluence with the New Hope River and $0.3 \mathrm{~km}(0.2 \mathrm{mi})$ upstream from the Haywood station. The construction of coffer dams at the site in early 1970 and through the study period caused varying amounts of pooling and subsequent sedimentation, which decreased the amount of suspended sediment available for transport downstream. Suspended-sediment concentrations and yields downstream from the Haywood station are further decreased by inflow from Deep River, which had an average annual suspended-sediment yield of about $42 \mathrm{t} / \mathrm{km}^{2}$ (119 tons $/ \mathrm{mi}^{2}$ ) at the sampling station at Moncure during the study period. These effects of dilution and siltation are reflected in a yield of $52 \mathrm{t} / \mathrm{km}^{2}\left(148 \mathrm{tons} / \mathrm{mi}^{2}\right)$ for the Cape Fear River at Lillington.

Suspended-sediment concentrations for sampling stations having less than $777 \mathrm{~km}^{2}\left(300 \mathrm{mi}^{2}\right)$ of drainage area varied from negligible at all sites at extreme low flows to flood-flow concentrations of $578 \mathrm{mg} / \mathrm{l}$ in Cane Creek near Teer. Concentrations for the larger streams ranged from less than $20 \mathrm{mg} / \mathrm{l}$ at several sites during low flows to $1,620 \mathrm{mg} / \mathrm{l}$ for the Haw River at Haw River during flood flows.

Construction of the $5,800-\mathrm{hm}^{2}(14,300$-acre) B. Everett Jordan Dam is now nearing completion. The sediment regime of the Haw River will obviously be changed for a considerable distance downstream from the dam after it becomes operational, and suspendedsediment concentrations will be drastically reduced. It is reasonable to assume that over 90 percent of the sediment entering the lake will be trapped. During the study period, the two sampling stations immediately upstream from the lake site, New Hope River near Pittsboro and Haw River near Pittsboro, had average annual suspended-sediment yields of 32 and $80 \mathrm{t} / \mathrm{km}^{2}$ (90 and 229 tons/ $\mathrm{mi}^{2}$ ), respectively. A rough approximation of the amount of sediment that will be trapped by the new lake can be made by multi- 
plying the average annual yield of each station times the respective drainage area, adding these amounts, and then deducting the 10 percent or less of the total which would probably flow through the lake. By these calculations, about $272,000 \mathrm{t}(300,000$ tons $)$ or $0.17 \mathrm{hm}^{3}$ (140 acre-feet) of sediment will be trapped annually, providing that hydrologic and environmental conditions remain virtually within the bounds that prevailed during the study period.

\section{PARTICLE SIZE OF SUSPENDED SEDIMENT}

Available particle-size data were obtained from samples collected at random intervals only during periods of high flow; thus a comparative relationship of size versus range in flow is not possible. Figure 9 shows the results of particle-size analyses for selected flood samples.

The sizes of material transported in suspension are dependent not only upon stream discharge and flow but also upon the supply of material available for transport. Most of the streams in the Piedmont region have the high velocities needed to keep coarser materials in suspension, and there is also an abundant supply of erodible soil. Silts and sands generally compose more than 50 percent of the suspended materials in Piedmont streams during floods, as indicated by the data in figure 9. Excluding the 2 Piedmont stations, Swift Creek at Hilliardston and Little Fishing Creek near White Oak, which have physical and hydrologic characteristics similar to those of Coastal Plain streams, the data in figure 9 also show a range for silt and sand of about 40 to 70 percent of the total measurable load in flooding Piedmont streams.

In the Coastal Plain region stream gradients are very low, and flow velocities are usually not high enough, even at flood stages, to carry a high proportion of the coarser material although there is an almost unlimited supply of coarse material available for transport. Because of the gentle surface slopes in the Coastal Plain region, the velocity of overland runoff during intense rainstorms is also usually insufficient to transport particles coarser than clay size to the major stream systems. Figure 9 shows that during floods clay-size particles compose about 60 to 70 percent of the suspended material transported by Coastal Plain streams.

\section{SUMMARY}

The data obtained indicate that the average annual suspendedsediment yields for streams are highly variable and ranged from 117 to $4.2 \mathrm{t} / \mathrm{km}^{2}$ (333 to 12 tons $/ \mathrm{mi}^{2}$ ) during $1969-73$. The highest sediment yields occur in the Piedmont region and the lowest in the 


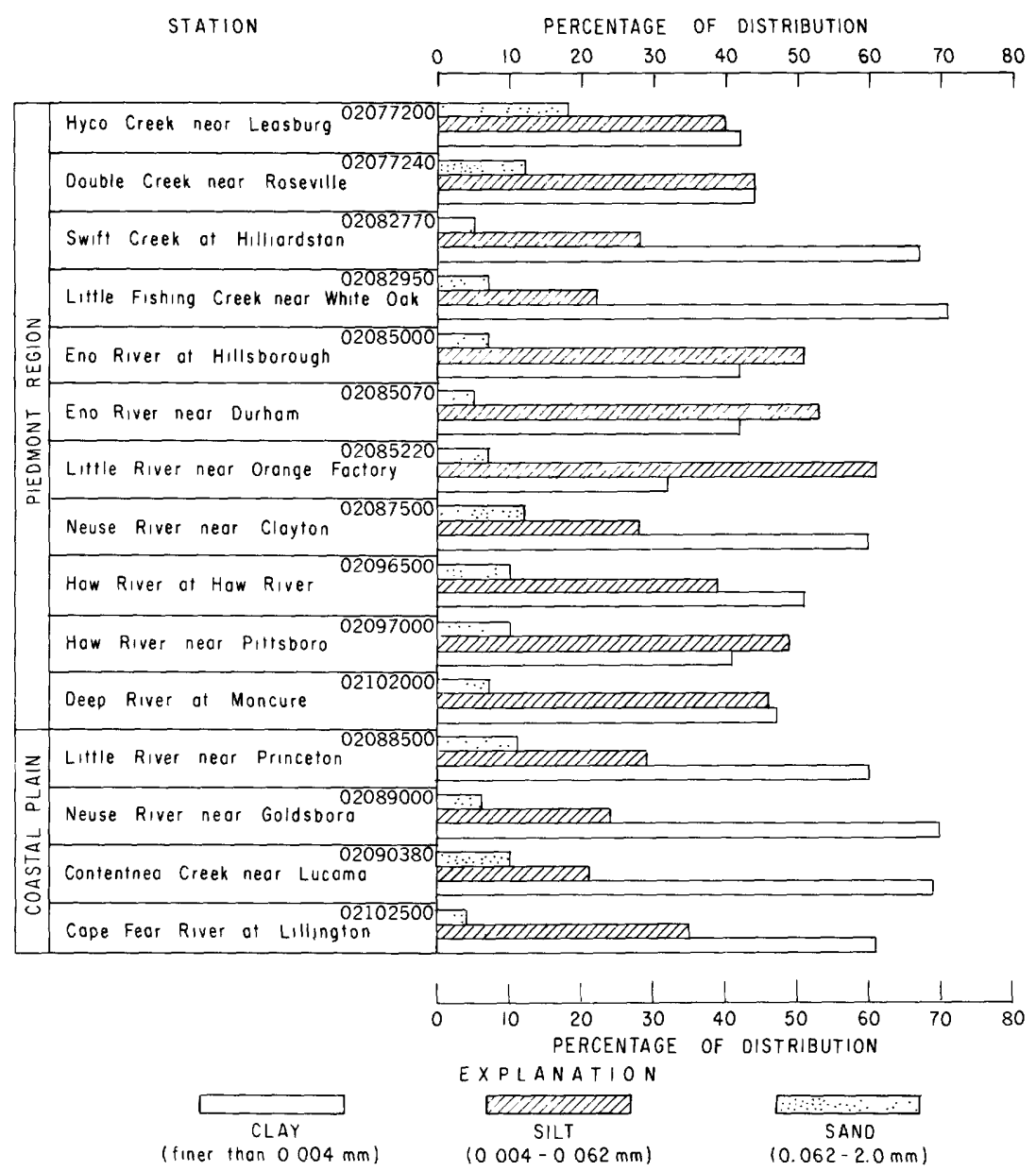

Figure 9.-Percentage distribution of clay, silt, and sand in suspended-sediment samples collected during floods at selected stations, 1969-73.

Coastal Plain. There is a very sharp decrease in suspended-sediment concentration in an eastward direction from the Piedmont to the Coastal Plain region. The major contributing factors that affect yields are topography, the erodibility of the soils, runoff, and manmade detention structures. Most of the sediment is transported during periods of high storm runoff, which account for only a small percentage of the total time during each year. Large lakes or reservoirs in a stream basin have a significant effect on the continuity of the sediment regime of the basin by serving as sediment-detention traps, thereby reducing the amount of suspended sediment available for transport for a considerable distance downstream from the impoundment. 
Land use also has a pronounced effect on the sediment characteristics of streams in the Piedmont province. Basins in the Piedmont with large percentages of forest cover are characterized by lower sediment yields; however, no obvious relationship between land cover and sediment characteristics was observed for streams in the Coastal Plain region.

Particle-size analyses of suspended-sediment samples obtained during floods indicate that generally over 50 percent of the suspended material in Piedmont streams is in the range of silt and sand, whereas suspended material in flooded Coastal Plain streams is mostly clay size.

While the data are representative of the sediment characteristics in the area during the 5-year study period, the data should also be indicative of long-term characteristics, excluding, of course, the effects of very large floods or other unusual hydrologic events.

\section{SELECTED REFERENCES}

Chang, F. M., Simons, D. B., and Richardson, E. V., 1965, Total bed-material discharge in alluvial channels: U.S. Geol. Survey Water-Supply Paper 1498-I, $23 \mathrm{p}$.

Colby, B. R., 1956, Relationship of sediment discharge to streamflow: U.S. Geol. Survey open-file report, $170 \mathrm{p}$.

Goddard, G. C., Jr., and others, 1970, A proposed streamflow data program for North Carolina, U.S. Geol. Survey open-file report, $69 \mathrm{p}$.

Guy, H. P., 1960, Effects of urbanization on sediment in streams: Meeting of Chesapeake Section of American Water Works Association, Nov. 4, 1960, $17 \mathrm{p}$.

1973, Laboratory theory and methods for sediment analysis: U.S. Geol. Survey Techniques Water-Resources Inv., book 5, chap. C1, 58 p.

Guy, H. P., and Norman, V. W., 1970, Field methods for measurement of fluvial sediment: U.S. Geol. Survey Techniques Water-Resources Inv., book 3, chap. C2, 59 p.

Lee, W. D., 1955, The soils of North Carolina: North Carolina Agr. Expt. Sta. Tech. Bull. 115, $187 \mathrm{p}$.

Malcom, H. R., 1972, Urban sedimentation viewed as an economic externality: Dept. of Civil Engr., N.C. State University, 15 p.

Miller, C. R., 1951, Analysis of flow-duration, sediment-rating curve method of computing sediment yield: U.S. Bur. of Reclamation, Hydrology Br., 55 p.

North Carolina Department of Conservation and Development, 1958, Geologic map of North Carolina.

Reeder, H. E., 1973, Sediment resulting from construction of an interstate highway in the Piedmont area of North Carolina: U.S. Geol. Survey openfile report, $27 \mathrm{p}$. 
U.S. Department of Agriculture, 1965, Rainfall-erosion losses from cropland east of the Rocky Mountains: U.S. Dept. of Agriculture, Agriculture Handb. 282, 47 p.

1967, North Carolina Conservation Needs Inventory: U.S. Dept. of Agr., 194 p.

U.S. Geological Survey, issued annually for 1969-73 water years, Water resources data for North Carolina; pt. 2, water quality records: U.S. Geol. Survey basic data releases. 
TABLE 5 
TABLE 5.-Locations of sampling stations used in this report

\begin{tabular}{|c|c|c|}
\hline $\begin{array}{c}\text { USGS } \\
\text { station } \\
\text { No. }\end{array}$ & Station name & Location \\
\hline
\end{tabular}

$02077200 \_$Hyco Creek near Leasburg__._Lat $36^{\circ} 24^{\prime} 07^{\prime \prime}$, long $79^{\circ} 12^{\prime} 13^{\prime \prime}$, Caswell County, at bridge on U.S. Highway 158, 1.5 miles upstream from Kilgore Creek, and 2.5 miles west of Leasburg.

$02077240 \_$Double Creek near Roseville__Lat $36^{\circ} 21^{\prime} 44^{\prime \prime}$, long $79^{\circ} 05^{\prime} 48^{\prime \prime}$, Person County, at bridge on Secondary Road 1166, 1.0 mile upstream from Mill Creek, and 3.0 miles northwest of Roseville.

02077250_-_South Hyco Creek near Roseville.

Lat $36^{\circ} 23^{\prime} 12^{\prime \prime}$, long $79^{\circ} 06^{\prime} 22^{\prime \prime}$, Person County, at bridge on U.S. Highway 158, 1.2 miles downstream from Double Creek, and 4.2 miles northwest of Roseville.

02077300__ Hyco River at McGehees Mill.

Lat $36^{\circ} 31^{\prime} 02^{\prime \prime}$, long $79^{\circ} 01^{\prime} 42^{\prime \prime}$, Person County, at bridge on Secondary Road 1322, at McGehees Mill, and 1.7 miles downstream from Hyco Lake.

$02081500_{-}$Tar River near Tar River_____Lat $36^{\circ} 11^{\prime} 41^{\prime \prime}$, long $78^{\circ} 35^{\prime} 00^{\prime \prime}$, Granville County, at Bridge on State Highway 96, 1.2 miles upstream from Fishing Creek, 2.5 miles east of town of Tar River, and 8 miles south of Oxford.

$02081800_{-}$Cedar Creek near Louisburg_-Lat $36^{\circ} 03^{\prime} 14^{\prime \prime}$, long $78^{\circ} 20^{\prime} 24^{\prime \prime}$, Franklin County, at bridge on U.S. Highway 401, 0.8 mile downstream from Camping Creek, 3.7 miles southwest of Louisburg, and 5.5 miles upstream from mouth.

$02082770_{-}$Swift Creek at Hilliardston__-Lat $36^{\circ} 06^{\prime} 42^{\prime \prime}$, long $77^{\circ} 55^{\prime} 16^{\prime \prime}$, Nash County, at bridge on Secondary Road 1310, 0.7 mile northeast of Hilliardston, and 2.8 miles from Gideon Swamp.

02082950 __Little Fishing Creek near White Oak.

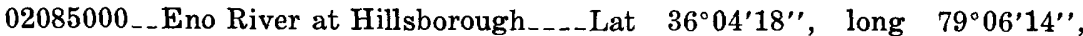
Orange County, at bridge on State Highway 86, at Hillsborough, and 2 miles downstream from Sevenmile Creek.

$02085070_{-}$Eno River near Durham_____Lat $36^{\circ} 04^{\prime} 21^{\prime \prime}$, long $78^{\circ} 54^{\prime} 24^{\prime \prime}$, Durham County, at Bridge on U.S. Highway 501, 0.2 mile downstream from Crooked Creek, and 5 miles north of Durham.

02085220__Little River near Orange Factory.
Lat $36^{\circ} 08^{\prime} 20^{\prime \prime}$, long $78^{\circ} 54^{\prime} 24^{\prime \prime}$, Durham County, at bridge on 
PIEDMONT AND COASTAL PLAIN, NORTH CAROLINA O31

TABLE 5.-Locations of sampling stations used in this report-Continued

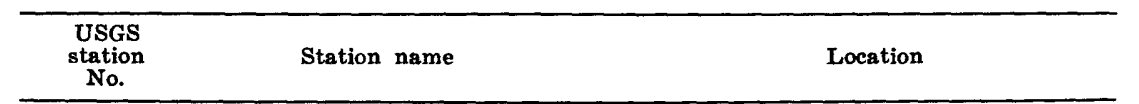

U.S. Highway 501, 1 mile upstream from Mountain Creek, and 1.2 miles northwest of Orange Factory.

$02086000 \ldots$ Dial Creek near Bahama _.__Lat $36^{\circ} 01^{\prime} 36^{\prime \prime}$, long $78^{\circ} 51^{\prime} 24^{\prime \prime}$, Durham County, 0.4 mile upstream from bridge on Secondary Road 1616 and Lake Michie, and 1.5 miles northeast of Bahama.

$02087000_{-}$Neuse River near Northside__Lat $36^{\circ} 02^{\prime} 54^{\prime \prime}$, long $78^{\circ} 44^{\prime} 59^{\prime \prime}$, Durham County, at Fish Dam Bridge on Secondary Road 1801, 1.5 miles downstream from Rocky Creek, 2.5 miles downstream from Seaboard Coast Line Railroad bridge, 2.5 miles south of Northside, 8.5 miles downstream from confluence of Eno and Flat Rivers, and 9.5 miles northeast of Durham.

02087182_-Neuse River near Falls______Lat 35 $56^{\prime} 24^{\prime \prime}$, long 78 $34^{\prime} 32^{\prime \prime}$, Wake County, at bridge on Secondary Road 2000, 0.4 mile northeast of Falls, and 0.5 mile downstream from Honeycutt Creek.

02087500__Neuse River near Clayton_.__Lat $35^{\circ} 38^{\prime} 50^{\prime \prime}$, long $78^{\circ} 24^{\prime} 21^{\prime \prime}$, Johnston County, at bridge on State Highway 42, 2.3 miles upstream from Mill Creek, and 3 miles east of Clayton.

$02088000_{-}$Middle Creek near Clayton_-_Lat $35^{\circ} 34^{\prime} 12^{\prime \prime}$, long $78^{\circ} 35^{\prime} 30^{\prime \prime}$, Johnston County, at bridge on State Highway 50, 0.5 mile upstream from Buffalo Branch, 3.7 miles downstream from WakeJohnston County line, and 9.5 miles southwest of Clayton.

02088470__Little River near Kenly__.___Lat $35^{\circ} 35^{\prime} 18^{\prime \prime}$, long $78^{\circ} 11^{\prime} 12^{\prime \prime}$, Johnston County, at bridge on Secondary Road 1934, 0.7 mile downstream from Buffalo Creek, and 3.7 miles west of Kenly.

02088500__Little River near Princeton__Lat $35^{\circ} 30^{\prime} 40^{\prime \prime}$, long $78^{\circ} 09^{\prime} 36^{\prime \prime}$, Johnston County, at bridge on Secondary Road 2320, 0.8 mile upstream from Little Creek, and 3 miles north of Princeton.

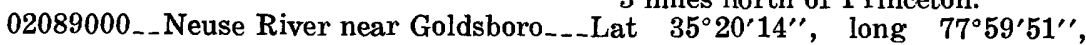
Wayne County, at bridge on Secondary Road 1915, 0.2 mile upstream from Stony Creek, 1.5 miles downstream from Seaboard Coast Line Railroad bridge, 3.2 miles south of Wayne County courthouse in Goldsboro, 4.3 miles downstream from Little River, and 135 miles upstream from mouth. 
TABLE 5.-Locations of sampling stations used in this report-Continued

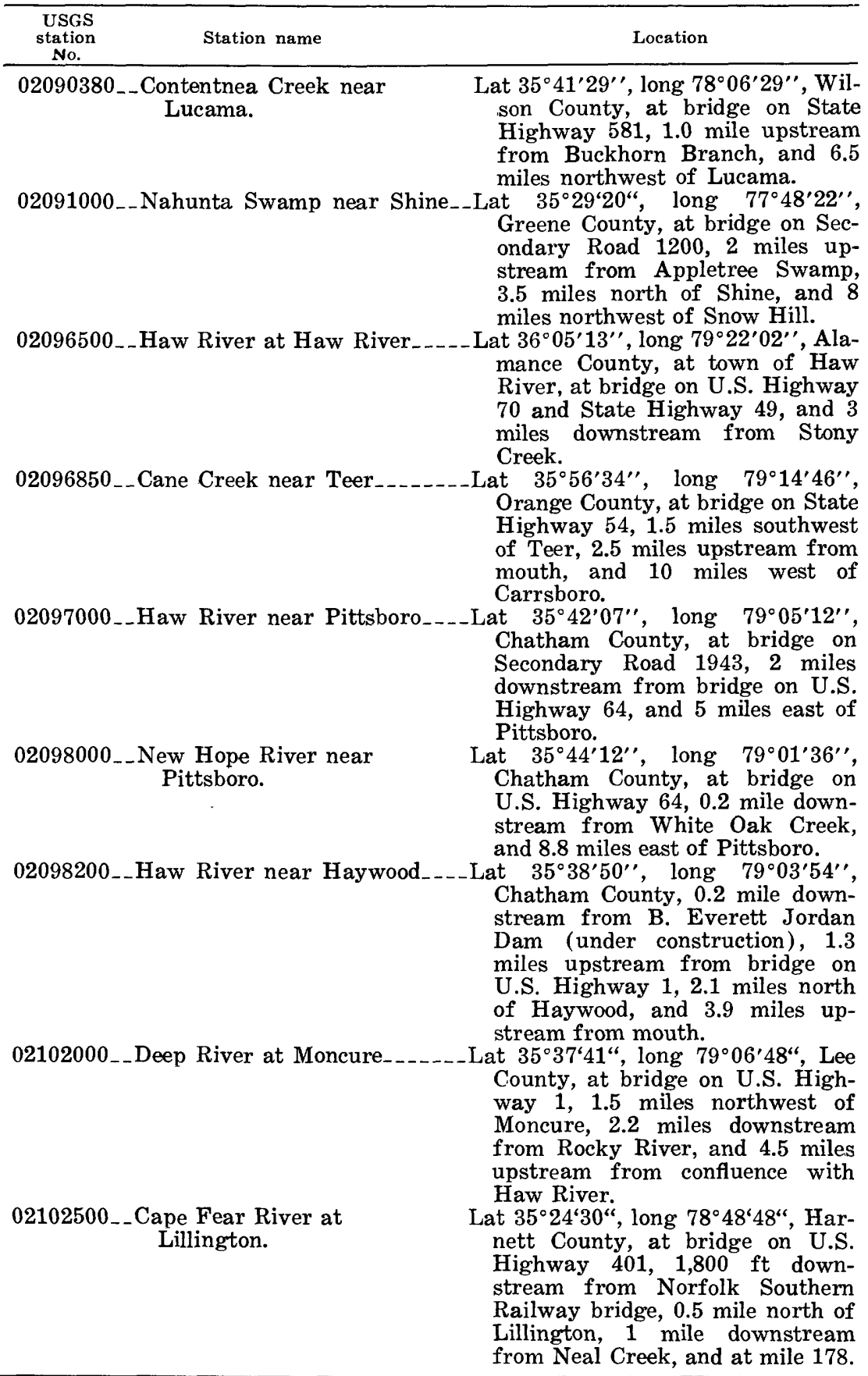



